\title{
Bacillus thermoamylovorans sp. nov., a Moderately Thermophilic and Amylolytic Bacterium
}

\author{
Y. COMBET-BLANC, ${ }^{1 *}$ B. OLLIVIER, ${ }^{1}$ C. STREICHER,${ }^{1}$ B. K. C. PATEL,${ }^{2}$ P. P. DWIVEDI, ${ }^{2}$ \\ B. POT, ${ }^{3}$ G. PRENSIER, ${ }^{4}$ AND J.-L. GARCIA ${ }^{1}$ \\ Laboratoire de Microbiologie ORSTOM, Université de Provence, 13331 Marseille Cedex $3,{ }^{1}$ and Laboratoire de Microbiologie, \\ Université Blaise Pascal, 63177 Aubière Cedex, ${ }^{4}$ France; Faculty of Science and Technology, Griffith University, Brisbane, \\ Queensland 4111, Australia ${ }^{2}$; and Laboratorium voor Microbiologie, Universiteit Gent, B-9000 Ghent, Belgium ${ }^{3}$
}

\begin{abstract}
A moderately thermophilic, facultatively anaerobic, amylolytic bacterium was isolated from palm wine, a tropical alcoholic beverage that was sampled in Senegal. The cells were gram positive, catalase positive, non-spore forming, rod shaped, and slightly motile with peritrichous flagella. The strain which we examined did not possess cytochrome and produced $\mathrm{L}-(+)$-lactate, acetate, ethanol, and formate but not hydrogen during carbohydrate fermentation. Growth occurred at $\mathrm{pH}$ values ranging from 5.4 to 8.5 , and optimum growth occurred at around $\mathrm{pH} \mathrm{7.0}$. The optimum temperature for growth was around $50^{\circ} \mathrm{C}$, and the upper temperature limit for growth was $58^{\circ} \mathrm{C}$. The guanine-plus-cytosine content of the DNA was $38.8 \pm 0.2 \mathrm{~mol} \%$. A sequence analysis of the 16S rRNA gene revealed that the new organism is closely related phylogenetically to members of genus Bacillus. Despite the lack of spores, we propose that on the basis of phylogenetic characteristics, the new isolate should be classified as a new Bacillus species, Bacillus thermoamylovorans. The type strain is strain DKP (= Collection of Institut Pasteur CNCM I-1378).
\end{abstract}

Palm wine is the collective name of alcoholic beverages that result from spontaneous fermentation of the sap of any species of tree belonging to the large family Palmae. This traditional beverage is prepared in the tropical areas of Africa, Asia, and South America where palm trees are common (27). The sap is collected from a newly made slit at the base of an immature male inflorescence on a tree. Leaking sap is collected in a calabash, through a channel made from a plaited palm leaf (48). This method allows daily collection of about 10 liters of sap per tree (16). The sap contains about 10 to $15 \%$ (wt/vol) sucrose $(12,45)$, amino acids $(51)$, and vitamins $(2,6,38,49)$.

High densities of bacteria $\left(10^{7}\right.$ to $4 \times 10^{8}$ cells $\left.\mathrm{ml}^{-1}\right)$ and yeasts $\left(2 \times 10^{5}\right.$ to $10^{8}$ cells $\left.\mathrm{ml}^{-1}\right)(45)$ give palm wine a milky flocculent appearance (29). The bacteria and yeasts isolated from palm wine belong almost exclusively to the genera Lactobacillus and Saccharomyces, respectively (30, 41, 45, 46, 51 , which are both adapted to the high osmotic pressures and acidity that occur in fermented beverages (beer, grape wine, and cider) (21). Microbiological studies of palm wine have shown that the stage of fermentation markedly affects the diversity of the microflora.

During the early stages of production, when the sap has a neutral $\mathrm{pH}$ ( $\mathrm{pH} 7.0$ to 7.2) and contains a high concentration of sucrose, numerous species belonging mostly to the genera Leuconostoc, Lactobacillus, Streptococcus, Saccharomyces, Schizosaccharomyces, Candida, and Pichia have been isolated from palm wine $(30,41,51)$; a few Clostridium or Bacillus spp. and gramnegative Serratia and Klebsiella spp. have also been isolated $(30,45)$. This diverse microbiota ferments the sucrose within about $30 \mathrm{~h}(12,38)$, and this fermentation leads to acidification of the medium through the production of organic acids, mostly lactic acid. The decrease in $\mathrm{pH}$ results in (i) the selection of acidophilic species and (ii) the disappearance of gram-negative

* Corresponding author. Mailing address: Laboratoire de Microbiologie ORSTOM, Université de Provence, Case 87, 3 Place VictorHugo, 13331 Marseille Cedex 03, France. Phone: 33-91106478. Fax: 33-91106481. bacteria, as well as pathogenic bacteria, that are not adapted to low $\mathrm{pH}$ values (45).

After about 4 days of fermentation, Lactobacillus species tend to disappear, while members of the genera Streptococcus and Micrococcus become dominant along with yeasts $(30,41$, 45). Later, the accumulation of ethanol and the low $\mathrm{pH}$ of the medium favor the growth of acetic acid-producing bacteria, which oxidize ethanol to acetic acid. Despite the selectivity of the ecosystem, some Clostridium and Bacillus spp. survive in this environment, probably because of their ability to sporulate. As the mesophilic bacteria involved in palm wine production have already been studied $(6,30,41,45,46,51)$ and as thermophilic lactobacilli belonging to the subgenus Thermobacterium have been isolated previously from grape wine by Barre (5), we focused on the thermophilic anaerobic flora in palm wine. During this study we isolated two thermophilic species, Clostridium thermopalmarium (23) and a thermophilic amylolytic bacterium whose characteristics are described and discussed in this paper.

\section{MATERIALS AND METHODS}

Origin of the isolate. Strain $\mathrm{DKP}^{\mathrm{T}}(\mathrm{T}=$ type strain) was isolated from a sample of palm wine collected in Rufisque ( $20 \mathrm{~km}$ east of Dakar), Senegal.

Culture methods and media. Hungate's anaerobic techniques $(17,25)$ were used in the experiments described below. Strain DKP ${ }^{\mathrm{T}}$ was cultured on a basal medium containing (per liter) $5.0 \mathrm{~g}$ of yeast extract (Difco Laboratories, Detroit, Mich.), $5.0 \mathrm{~g}$ of Biotrypcase (bioMérieux, Craponne, France), $1.0 \mathrm{~g}$ of $\mathrm{KH}_{2} \mathrm{PO}_{4}$, $0.4 \mathrm{~g}$ of $\mathrm{MgCl}_{2} \cdot 6 \mathrm{H}_{2} \mathrm{O}, 1.0 \mathrm{~g}$ of $\mathrm{NH}_{4} \mathrm{Cl}, 5.0 \mathrm{mg}$ of $\mathrm{FeSO}_{4} \cdot 7 \mathrm{H}_{2} \mathrm{O}, 25 \mathrm{ml}$ of a mineral solution (4), $1 \mathrm{ml}$ of a trace element solution (4), and $1 \mathrm{ml}$ of Tween 80 . The $\mathrm{pH}$ of this medium was adjusted to 7.5 with $10 \mathrm{M} \mathrm{KOH}$, and the medium was boiled and cooled under a stream of $\mathrm{O}_{2}$-free $\mathrm{N}_{2}$ at room temperature. It was then distributed into $60-\mathrm{ml}$ serum bottles $(20 \mathrm{ml}$ of medium per bottle) and Hungate tubes $(4.5 \mathrm{ml}$ of medium per tube) (28). After the medium was autoclaved at $110^{\circ} \mathrm{C}$ for $45 \mathrm{~min}$, energy sources were injected into the serum bottles and Hungate tubes from separately sterilized stock solutions to give a final concentration of $0.3 \%$ (wt/vol)

A vitamin-free, chemically defined medium was used to determine vitamin requirements. This medium contained (per liter) $1.0 \mathrm{~g}$ of $\mathrm{KH}_{2} \mathrm{PO}_{4}, 0.4 \mathrm{~g}$ of $\mathrm{MgCl}_{2} \cdot 6 \mathrm{H}_{2} \mathrm{O}, 0.2 \mathrm{~g}$ of $\mathrm{NH}_{4} \mathrm{Cl}, 5.0 \mathrm{mg}$ of $\mathrm{FeSO}_{4} \cdot 7 \mathrm{H}_{2} \mathrm{O}, 25 \mathrm{ml}$ of a mineral solution (4), $1 \mathrm{ml}$ of a trace element solution (4), $1 \mathrm{ml}$ of Tween $80,0.26 \mathrm{mmol}$ of DL-cysteine, $0.26 \mathrm{mmol}$ of L-lysine, $0.26 \mathrm{mmol}$ of L-tryptophan, $0.26 \mathrm{mmol}$ of $\mathrm{L}-(+)$-asparagine, $0.26 \mathrm{mmol}$ of L-glutamine, $0.26 \mathrm{mmol}$ of DL-tyrosine, 0.26 mmol of DL-phenylalanine, $0.26 \mathrm{mmol}$ of DL-threonine, $0.26 \mathrm{mmol}$ of DL-aspartic 
acid, $0.26 \mathrm{mmol}$ of L-isoleucine, $0.26 \mathrm{mmol}$ of DL-serine, $0.26 \mathrm{mmol}$ of DL-valine $0.26 \mathrm{mmol}$ of L-histidine-HCL, $0.26 \mathrm{mmol}$ of DL-leucine, $0.26 \mathrm{mmol}$ of glycine $0.26 \mathrm{mmol}$ of DL-alanine, $0.26 \mathrm{mmol}$ of DL-proline, $0.26 \mathrm{mmol}$ of L-arginine, 0.26 mmol of DL-methionine, and $0.26 \mathrm{mmol}$ of L-glutamic acid (all amino acids from Sigma Chemical Co., St. Louis, Mo.). The $\mathrm{pH}$ of the medium was adjusted to 7.5 with $10 \mathrm{M} \mathrm{KOH}$. The medium was then distributed under a stream of $\mathrm{O}_{2}$-free $\mathrm{N}_{2}$ into Hungate tubes $(4.5 \mathrm{ml}$ of medium per tube $)$ and autoclaved at $110^{\circ} \mathrm{C}$ for 40 min. Glucose, vitamins, and purine and pyrimidine bases were injected into the Hungate tubes from filter-sterilized solutions.

Unless indicated otherwise, all experiments were conducted at the optimum temperature for growth $\left(50^{\circ} \mathrm{C}\right)$ and $\mathrm{pH} 7.5$

Enrichment and isolation procedure. Enrichment cultures were obtained by adding $10 \mathrm{ml}$ of palm wine, $1 \mathrm{ml}$ of $10 \% \mathrm{NaHCO}_{3}$, and $0.2 \mathrm{ml}$ of $2 \% \mathrm{Na}_{2} \mathrm{~S} \cdot 9 \mathrm{H}_{2} \mathrm{O}$ to a serum bottle containing $20 \mathrm{ml}$ of basal medium supplemented with $0.3 \%$ glucose. After $24 \mathrm{~h}$ at $50^{\circ} \mathrm{C}$, a $1-\mathrm{ml}$ sample was injected into another serum bottle containing basal medium. This process was repeated twice. Pure cultures were obtained by repeated application of the roll tube method of Hungate (17). Single colonies were removed, preparations were diluted serially in Hungate tubes containing $4.5 \mathrm{ml}$ of basal medium supplemented with $0.3 \%$ glucose, and the tubes were incubated for $24 \mathrm{~h}$ at $50^{\circ} \mathrm{C}$. Strain $\mathrm{DKP}^{\mathrm{T}}$ was stored in liquid growth medium at room temperature and was used for further characterization.

Sporulation test. Two agar-based media were used to test for sporulation. Medium A contained (per liter) $5.0 \mathrm{~g}$ of Bacto Peptone (Difco), $3.0 \mathrm{~g}$ of meat extract (Difco), $5 \mathrm{mg}$ of $\mathrm{MnSO}_{4}$, and $16 \mathrm{~g}$ of agar (Difco).

Medium B, which was used for plates, was the same as the basal medium except that $1 \%$ glucose and $1.6 \%$ agar were added. The $\mathrm{pH}$ of medium $\mathrm{A}$ and the $\mathrm{pH}$ of medium $\mathrm{B}$ were adjusted to $\mathrm{pH} 7.2$ with $10 \mathrm{M} \mathrm{KOH}$. After autoclaving at $110^{\circ} \mathrm{C}$ for $45 \mathrm{~min}$, the media were distributed into plates. The plates were inoculated with $0.3-\mathrm{ml}$ portions of an overnight liquid culture and then incubated at $50^{\circ} \mathrm{C}$ for up to 5 days to determine the presence of spores.

The heat resistance of cells was determined in basal medium supplemented with $0.3 \%$ glucose. After 1,2 , and 20 days of incubation at $50^{\circ} \mathrm{C}$, duplicate cultures were heated at $80^{\circ} \mathrm{C}$ for 5 and $10 \mathrm{~min}$ and subcultured into fresh medium (inoculum, 20\% [vol/vol]), and the resulting preparations were incubated $48 \mathrm{~h}$ at $50^{\circ} \mathrm{C}$. In addition, the viability of cells after 1,2 , and 20 days of incubation was checked by subculturing before heating.

Analytical techniques. Bacterial growth was monitored by measuring the increase in turbidity at $600 \mathrm{~nm}$ in anaerobic Hungate tubes inserted directly into a Shimadzu model UV 160A spectrophotometer. The effect of oxygen on the growth and metabolism of strain $\mathrm{DKP}^{\mathrm{T}}$ was determined in flasks which contained basal medium supplemented with $1 \%$ glucose and were agitated. Hungate tubes containing basal medium supplemented with $0.3 \%$ glucose with air or $\mathrm{O}_{2}$-free $\mathrm{N}_{2}$ in the headspace were also used. Flasks and Hungate tubes were inoculated (inoculum, $10 \%$, [vol $/ \mathrm{vol}]$ ) with overnight cultures and incubated for $48 \mathrm{~h}$ at $50^{\circ} \mathrm{C}$.

The fermentation pattern was determined in duplicate by using basal medium containing the carbohydrate being tested at a final concentration of $0.3 \%(\mathrm{wt} / \mathrm{vol})$ and $0.017 \%$ bromothymol blue. Stock carbohydrates were sterilized separately by filtration.

The vitamin requirements were determined by using the vitamin-free chemically defined medium supplemented with glucose at a final concentration of $0.3 \%$ (wt/vol). A vitamin solution, an adenine-guanine-uracil solution, and a xanthine solution were prepared as described by Rogosa et al. (37) and were sterilized separately by filtration. The final concentrations of the vitamins and purine and pyrimidine bases tested were as follows: nicotinic acid, thiamine-HCL, calcium D-pantothenate, and ribollavin, $992 \mu \mathrm{g} \mathrm{liter}^{-1} ; p$-aminobenzoic acid, $551 \mu \mathrm{g}$ liter ${ }^{-1}$; pyridoxine, $1,984 \mu$ liter $^{-1}$; vitamin $\mathrm{B}_{12}, 1 \mu \mathrm{g}$ liter $^{-1}$; DL-biotin, $10 \mu \mathrm{g}$ liter $^{-1}$; folic acid, $1 \mu \mathrm{g} \mathrm{liter}{ }^{-1}$; and adenine, guanine, uracil, and xanthine, 5.157 $\mathrm{mg}$ liter $^{-1}$. Actively growing cultures obtained after three successive transfers in basal medium were used for inoculation. Inocula were obtained from suspensions of organisms that had been washed twice in saline. For each growth factor, the test was performed in triplicate.

The temperature range for growth was determined by using thermostatically controlled water baths. Catalase activity was tested with a $3 \%$ (vol/vol) hydrogen peroxide solution by using a pellet resulting from centrifugation of $1.5 \mathrm{ml}$ of an overnight culture. Aerobiosis was achieved by shaking cultures growing in basal medium containing $1 \%$ glucose. Indole production and ammonium production were assayed with Kovács and Nessler's reagents (Sigma), respectively. Nitrate reduction was determined with Griess's reagent (Sigma). $\mathrm{H}_{2} \mathrm{~S}$ was measured photometrically as colloidal CuS after reaction with a mixture containing $50 \mathrm{mM}$ $\mathrm{HCl}$ and $5 \mathrm{mM} \mathrm{CuSO}_{4}(9)$.

Glucose and fermentation product contents were determined by high-performance liquid chromatography (HPLC), using a model Analprep 93 pump (Touzart et Matignon, Vitry sur Seine, France) and a type ORH 801 column (Interaction Chemicals, Inc., Mountain View, Calif.) equipped with a differential refractometer detector (Knauer, Berlin, Germany). A 20- $\mu$ l portion of a cell-free supernatant was injected into the column, which was maintained at $35^{\circ} \mathrm{C}$. A 25 $\mathrm{mM} \mathrm{H} \mathrm{SO}_{4}$ solution was used as the solvent at a flow rate of $0.7 \mathrm{ml} \cdot \mathrm{min}^{-1}$. Hydrogen was quantified by using a Girdel model Serie 30 gas chromatograph equipped with a thermal conductivity detector and a stainless steel column $(1 \mathrm{~m}$ by $3.2 \mathrm{~mm}$ ) packed with Carbosphere SS (60/80 mesh); the column temperature was $150^{\circ} \mathrm{C}$, the carrier gas was $\mathrm{He}\left(10^{5} \mathrm{~Pa}\right)$, the injector and detector temperature was $210^{\circ} \mathrm{C}$, and the power of the filament was $90 \mathrm{~mA} . \mathrm{CO}_{2}$ and $\mathrm{O}_{2}$ contents were determined with a Chrompack model CP 9000 gas chromatograph equipped with a thermal conductivity detector and two stainless steel columns ( $1.5 \mathrm{~m}$ by 2.2 $\mathrm{mm})$. One column was packed with molecular sieve 5A (60/80 mesh), and the other column was packed with silica gel (GC grade); the column temperature was $60^{\circ} \mathrm{C}$; the carrier gas was $\mathrm{He}\left(10^{5} \mathrm{~Pa}\right)$, the injector temperature was $70^{\circ} \mathrm{C}$, the detector temperature was $150^{\circ} \mathrm{C}$, and the power of the filament was $90 \mathrm{~mA}$. $\mathrm{L}-(+)$-Lactic dehydrogenase and $\mathrm{D}-(-)$-lactic dehydrogenase (Boeringer Mannheim, Mannheim, Germany) were used to assess the stereoisomerism of the lactic acid produced by the fermentation of glucose.

For cytochrome analysis, $3 \mathrm{~g}$ of wet cells suspended in $10 \mathrm{ml}$ of $20 \mathrm{mM}$ Tris hydrochloride buffer ( $\mathrm{pH} 7.6$ ) was sonicated eight times at $0.5 \mathrm{cycle} \cdot \mathrm{s}^{-1}$ for 2 min. The suspension was centrifuged at $30,000 \times g$ for $20 \mathrm{~min}$ at $5^{\circ} \mathrm{C}$ to remove the cell debris. The resulting cell extract was separated into a supernatant fraction and a particulate fraction by centrifugation at $140,000 \times g$ for $2 \mathrm{~h}$. The resulting dark gelatinous pellet was resuspended in the same buffer; this represented the particulate fraction. Both the soluble fraction and the particulate fraction were examined for cytochromes by determining their air-oxidized and dithionite-reduced spectra $(300$ to $600 \mathrm{~nm}$ ), as well as their redox difference spectra (dithionite-reduced spectrum minus air-oxidized spectrum), with a Shimadzu model UV 300 spectrophotometer.

Morphological characteristics. Morphological properties were determined by phase-contrast microscopy, using slides coated with a thin layer $(0.5 \mathrm{~mm})$ of purified agar (Difco). For electron microscopy preparations were negatively stained with $4 \%(\mathrm{wt} / \mathrm{vol})$ uranyl acetate in distilled water. For transmission electron microscopy cells were fixed for $1 \mathrm{~h}$ in $0.07 \mathrm{M}$ sodium cacodylate buffer ( $\mathrm{pH} 7.3$ ) containing $1.2 \%$ (wt/vol) glutaraldehyde and $0.05 \%$ ruthenium red. After the samples were washed in cacodylate buffer containing ruthenium red, they were postfixed with $1 \% \mathrm{OsO}_{4}$ in cacodylate buffer. The samples were embedded in Epon, and ultrathin sections were stained with $2 \%$ uranyl acetate in $50 \%$ ethanol and then with lead citrate. Micrographs were taken with a JEOL model $1200 \mathrm{CX}$ electron microscope.

DNA base composition. The guanine-plus-cytosine $(\mathrm{G}+\mathrm{C})$ content of the DNA was determined by workers at the Deutsche Sammlung von Mikroorganismen und Zellkulturen, Braunschweig, Germany. After disruption with a French pressure cell, the DNA was isolated and purified by chromatography on hydroxyapatite. The $\mathrm{G}+\mathrm{C}$ content was determined by HPLC as described by Meshbah et al. (26); nonmethylated lambda DNA (Sigma) was used as the internal standard.

SDS-PAGE. Approximately $90 \mathrm{mg}$ of cells was harvested from three bottles that contained basal medium supplemented with $0.3 \%$ of glucose and had been incubated at $50^{\circ} \mathrm{C}$ for $48 \mathrm{~h}$. Whole-cell protein extracts were prepared and sodium dodecyl sulfate (SDS)-polyacrylamide gel electrophoresis (PAGE) was performed as described by Pot et al. (33). Registration of the protein electrophoretic patterns, normalization of the densitometric traces, grouping of strains by using the Pearson product moment correlation coefficient, and an unweighted pair group using mathematical average cluster analysis were performed by the techniques described by Pot et al. (33), using the GELCOMPAR software package (version 2.0) (52). The protein profile of strain $\mathrm{DKP}^{\mathrm{T}}$ was compared with a database consisting of normalized protein fingerprints derived from reference strains belonging to almost all previously described species of lactic acid bacteria (32)

16S rRNA sequence studies. Purification of genomic DNA, amplification, and purification of the $16 \mathrm{~S}$ rRNA gene from isolate $\mathrm{DKP}^{\mathrm{T}}$ were performed by using a technique described previously $(24,35)$. The purified PCR product was sequenced directly. Sequencing was performed with an ABI automated DNA sequencer by using a Prism dideoxy terminator cycle sequencing kit as recommended by the manufacturer (Applied Biosystems, Ltd.). The primers used for sequencing have been described previously (35). The 16S ribosomal DNA sequence obtained from the sequencing data was aligned, by using sequence editor ae2, with the sequences of various members of the bacterial phylum whose 16S rRNA sequences were obtained from the Ribosomal RNA Database Project and from GenBank (22). Positions of sequence and alignment uncertainty were omitted from the analysis, and the pairwise evolutionary distances for 1,128 nucleotides were computed from levels of similarity by using the Olsen correction parameter (31) of Jukes and Cantor (18). Dendrograms were constructed from evolutionary distances by using the program of De Soete (10). A transversion analysis was performed by using the program DNAPARS implemented in the PHYLIP package (13). Tree topology was reexamined by using 100 bootstrapped data sets; the SEEQBOOT, DNADIST, FITCH, and CONSENSE programs available on TREECON (50) were used for this purpose.

Nucleotide sequence accession numbers. The strain $D_{K P^{T}}$ 16S rRNA sequence which we determined has been deposited in the GenBank database under accession number L27478. The EMBL accession numbers of the 16S rRNA sequences of Sporosarcina urea and Saccharococcus thermophilus are X62173 and X70430, respectively.

\section{RESULTS}

Colony morphology. After $48 \mathrm{~h}$ of growth on basal medium, strain $\mathrm{DKP}^{\mathrm{T}}$ colonies were small, white, lens shaped with smooth edges, and 2 to $3 \mathrm{~mm}$ in diameter. 

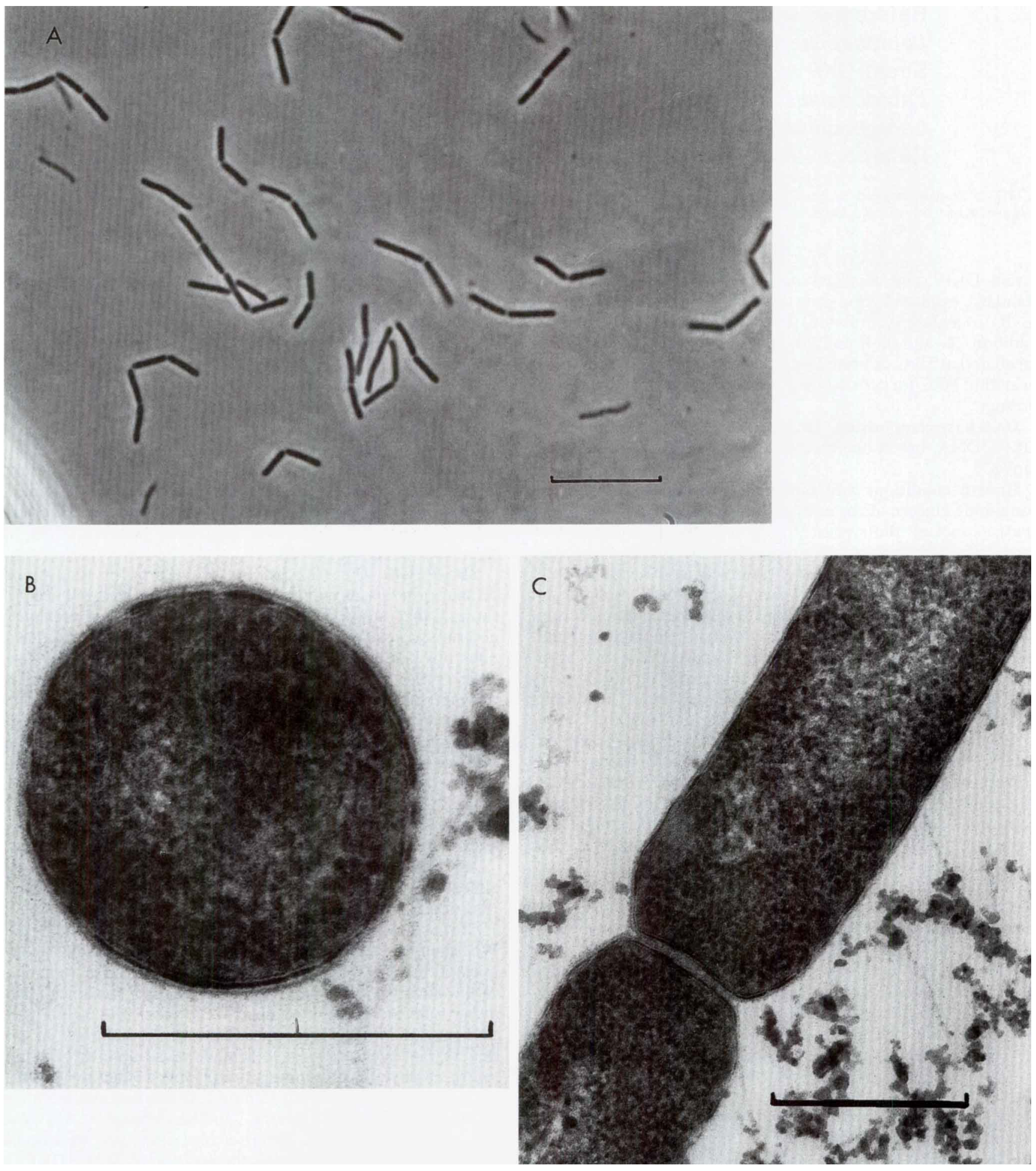

FIG. 1. (A) Phase-contrast photomicrograph of strain DKPT . Bar $=10 \mu \mathrm{m}$. (B) Uitrathin transverse section of isolate DKP ${ }^{\mathrm{T}}$, showing the cell wall structure. Bar $=0.5 \mu \mathrm{m}$. (C) Ultrathin longitudinal section of isolate $\mathrm{DKP}^{\mathrm{T}}$, showing the septum. Bar $=0.5 \mu \mathrm{m}$.

Cell morphology. Strain $\mathrm{DKP}^{\mathrm{T}}$ cells were straight rods that occurred either singly or in short chains of two to four cells (Fig. 1A). Although the cells possessed peritrichous flagella, they exhibited only very slight motility as determined by phase-contrast microscopy. The cells were 0.45 to $0.5 \mu \mathrm{m}$ wide and 3.0 to $4.0 \mu \mathrm{m}$ long. The Gram stain reaction was positive, but cells in older cultures lost the ability to retain the Gram stain. Thin sections revealed a typical gram-positive cell envelope profile (Fig. 1B and C). Strain $\mathrm{DKP} \mathrm{P}^{\mathrm{T}}$ did not grow on solid medium $\mathrm{A}$, which was used to induce sporulation of bacilli. 


\section{Reference strain for normalisation Lactobacillus paracasei Strain DKP$$
\text { Lactobacillus acidophilus }
$$$$
\text { Lactobacillus brevis }
$$$$
\text { Reference strain for normalisation }
$$

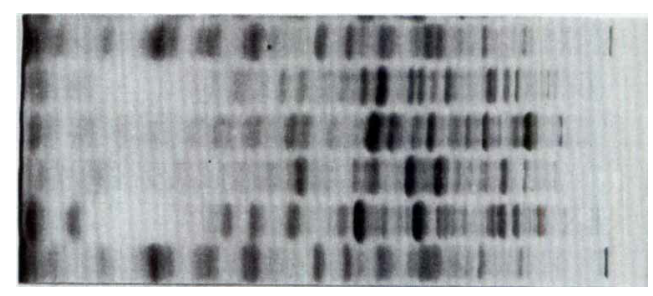

FIG. 2. Profiles obtained by electrophoretic analysis of whole-cell proteins of the following organisms: strain DKP ${ }^{\mathrm{T}}$, Lactobacillus paracasei, Lactobacillus acidophilus, and Lactobacillus brevis.

Strain $\mathrm{DKP}^{\mathrm{T}}$ and Bacillus coagulans, which was used as a standard, exhibited good growth on solid medium B. After 48 h, B. coagulans sporulated, but strain $\mathrm{DKP}^{\mathrm{T}}$ did not. In addition 24- and 48-h and 20-day-old cultures that had been incubated at $50^{\circ} \mathrm{C}$ exhibited no heat resistance when they were heated at $80^{\circ} \mathrm{C}$ for 5 or $10 \mathrm{~min}$, indicating that no spores were present.

DNA base composition. The average $\mathrm{G}+\mathrm{C}$ content of strain $\mathrm{DKP}^{\mathrm{T}}$ DNA, based on three determinations, was $38.8 \pm 0.2$ $\mathrm{mol} \%$.

Growth conditions and metabolic properties. In medium containing glucose as the energy source, strain $\mathrm{DKP}^{\mathrm{T}}$ required yeast extract or Biotrypcase for growth. No growth was observed when gelatin or casein replaced yeast extract. However, a small amount of growth was observed in the vitamin-free chemically defined medium when glucose was used as an energy source. Colonies grew on plates incubated in air. Strain $\mathrm{DKP}^{\mathrm{T}}$ also grew in liquid medium that had been agitated and in anaerobic medium with $\mathrm{O}_{2}$ in the headspace; in the latter medium the $\mathrm{O}_{2}$ was completely consumed and $\mathrm{CO}_{2}$ was produced. Strain $\mathrm{DKP}^{\mathrm{T}}$ also grew under strict anaerobic conditions in a prereduced medium. This indicated that strain $\mathrm{DKP}^{\mathrm{T}}$ is a facultative anaerobe. During anaerobic growth on glucose, strain $\mathrm{DKP}^{\mathrm{T}}$ produced lactate, formate, acetate, and ethanol as the only end products. No $\mathrm{H}_{2}$ was produced by strain $\mathrm{DKP}^{\mathrm{T}}$ even when it was cocultured with an hydrogenotrophic methanogen. At the end of the time course the fermentation balance measured was: 1.0 glucose $\rightarrow 0.89$ lactate +1.0 formate +0.56 acetate +0.57 ethanol.

Our data accounted for a level of carbon recovery of $99 \%$. The molar ratio of acetate, ethanol, and formate was 1:1:2. The lactate produced was $96 \% \mathrm{~L}-(+)$-lactate. Under aerobic conditions, strain $\mathrm{DKP}^{\mathrm{T}}$ produced lactate, acetate, and $\mathrm{CO}_{2}$ but not formate during glucose metabolism, and acetate production increased compared with acetate production under anaerobic conditions. Under aerobic conditions, the end products of glucose metabolism were: 1.0 glucose $\rightarrow 0.6$ lactate +1.21 acetate +0.06 ethanol $+1.21 \mathrm{CO}_{2}$.

However, strain $\mathrm{DKP}^{\mathrm{T}}$ lacked cytochromes but was positive for catalase activity. Nitrate reduction and sulfate reduction were negative, and indole and $\mathrm{H}_{2} \mathrm{~S}$ were not produced. In medium containing arginine as an energy source, $\mathrm{NH}_{3}$ was produced but no growth occurred.

Under anaerobic conditions, growth was optimal at approximately $50^{\circ} \mathrm{C} ; 58^{\circ} \mathrm{C}$ was the highest temperature at which growth occurred. The organism grew at $\mathrm{pH}$ values ranging from 5.4 to 8.5 ; the optimum $\mathrm{pH}$ was 7.0. In basal medium containing glucose as the energy source at $\mathrm{pH} 7.0$ and $50^{\circ} \mathrm{C}$, the maximum doubling time was $40 \mathrm{~min}$.

Fermentation of sugars. The following sugars (final concentration, $0.3 \%$ [wt/vol]) were fermented within $24 \mathrm{~h}$ : L-arabinose, D-ribose, D-glucose, D-fructose, D-mannose, L-rhamnose, amygdalin, arbutin, esculin, salicin, cellobiose, maltose, treha- lose, starch, glycogen, gentiobiose, and gluconate. D-Xylose, D-galactose, $N$-acetyl-D-glucosamine, lactose, sucrose, melezitose, and D-turanose were fermented slowly (within 48 to $96 \mathrm{~h}$ ). Glycerol, erythritol, D-arabinose, L-xylose, ribitol, L-sorbose, galactitol, inositol, D-mannitol, D-glucitol, $\alpha$-methyl-D-mannoside, $\alpha$-methyl-D-glucoside, melibiose, inulin, raffinose, xylitol, D-lyxose, D-tagatose, D- and L-fucose, D-arabitol, and L-arabitol were not fermented.

Vitamin requirements. Thiamine, DL-biotin, and purine and pyrimidine bases (adenine, guanine, uracil, xanthine) stimulated the growth of strain $\mathrm{DKP}^{\mathrm{T}}$ but were not essential. Vitamin $\mathrm{B}_{12}$, pyridoxine, nicotinic acid, $p$-aminobenzoic acid, calcium $\mathrm{D}$-pantothenate, folic acid, and riboflavin had no significant effect on growth.

SDS-PAGE. The electrophoretic patterns of the soluble cellular proteins, as determined by the PAGE method (Fig. 2), showed that strain $\mathrm{DKP}^{\mathrm{T}}$ is not similar to any previously described Lactobacillus or Carnobacterium species and that it does not belong to the genus Enterococcus, Lactococcus, or Vagococcus. Strain $\mathrm{DKP}^{\mathrm{T}}$ was also compared with the most relevant species of the genera Leuconostoc, Pediococcus, and Tetragenococcus and with a number of representative strains belonging to the genera Streptococcus and Bacillus, including Bacillus stearothermophilus, Bacillus thermoglucosida, and Bacillus thermoleovora strains and two Bacillus kaustophilus strains. Low correlation values were obtained, indicating that strain $\mathrm{DKP}^{\mathrm{T}}$ does not belong to any of the species mentioned above (data not shown).

16S rRNA sequence. Using 10 primers, we determined an almost complete sequence consisting of 1,542 bases for the $16 \mathrm{~S}$ ribosomal DNA gene of isolate $\mathrm{DKP}^{\mathrm{T}}$. Sequence positions 8 to 1542 (Escherichia coli numbering as described by Winker and Woese [53]) had 70 of the 70 signature nucleotides and/or nucleotide pairs which indicate that an organism is a member of the domain Bacteria (53). The results of a sequence alignment, followed by a phylogenetic analysis of the rRNA gene sequence in which representatives of the families of the domain Bacteria were used, indicated that strain $\mathrm{DKP}^{\mathrm{T}}$ belongs to the subphylum containing gram-positive bacteria with DNA $\mathrm{G}+\mathrm{C}$ contents of less than $55 \mathrm{~mol} \%$, which includes members of the genera Bacillus (groups 1 to 5 as defined by Ash et al. [3]), Sporolactobacillus, Sporosarcina, and Saccharococcus. Further analysis indicated that the position of isolate $\mathrm{DKP}^{\mathrm{T}}$ is equidistant from members of Bacillus groups 1, 2, and 5, with levels of similarity ranging from $93.9 \%$ for members of group 1 (Bacillus cereus, Bacillus subtilis, Bacillus circulans, Bacillus pantothenticus) and group 5 (B. kaustophilus, B. stearothermophilus, Bacillus thermoglucosidasius, and Saccharococcus thermophilus) to $93.4 \%$ for members of group 2 (Bacillus smithii, Bacillus globisporus, and Sporosarcina urea). Members of group 3 (Bacillus polymyxa) and Bacillus amylolyticus) and group 4 (Bacillus aneurinolyticus) were more distantly related (level of similarity, $89.1 \%$ ). Figure 3 is a dendrogram gener- 


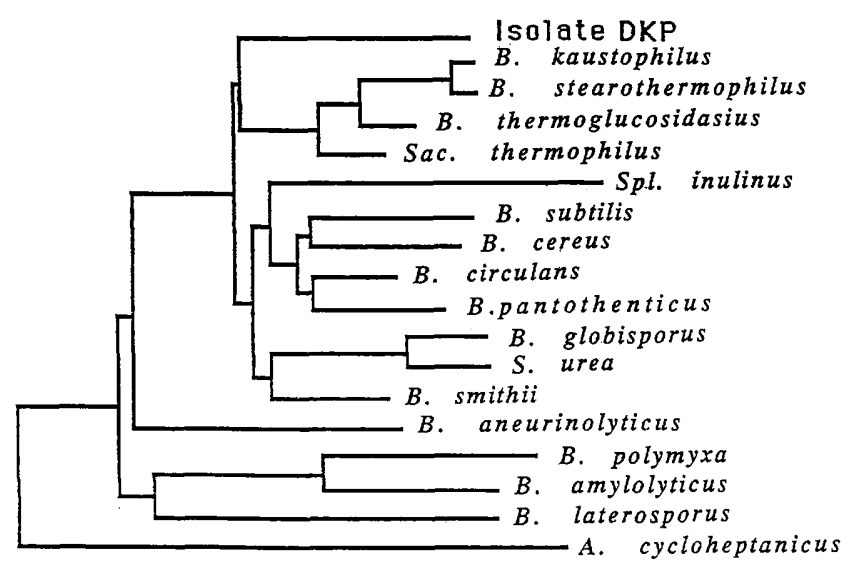

$10 \%$

FIG. 3. Dendrogram showing the position of isolate DKP ${ }^{\mathrm{T}}$ among representatives of the genus Bacillus and related bacteria. The dendrogram was derived from the similarity matrix shown in Table 1. Abbreviations: B., Bacillus; Sac., Saccharococcus; Spl., Sporolactobacillus; A., Alicyclobacillus; S., Sporosarcina.

ated by the method of De Soete (10) from the evolutionary distance matrix (Table 1) and shows these relationships. The $\mathrm{G}+\mathrm{C}$ content of the $16 \mathrm{~S}$ rRNA of isolate $\mathrm{DKP}^{\mathrm{T}}$ was 55.5 mol\%; this value is similar to the values determined for members of groups 1 to 5 but slightly lower than the values determined for members of group 5 (average $\mathrm{G}+\mathrm{C}$ content, 58 mol\%). A transversion analysis, implemented in the PHYLIP package, yielded results similar to those shown in Fig. 3, indicating that the results were not biased by the $\mathrm{G}+\mathrm{C}$ content of the 16S ribosomal DNA gene used in the analysis.

The following evidence supports the hypothesis that strain $\mathrm{DKP}^{\mathrm{T}}$ occupies an intermediate position in the cluster containing members of Bacillus groups 1,2, and 5. (i) Only two of the nine signature nucleotides that are found in members of the thermophilic bacilli belonging to group 5 as defined by Rainey et al. (34) were found in strain $\mathrm{DKP}^{\mathrm{T}}$, indicating a lack of close affiliation. And (ii) certain nucleotides, nucleotide pairs, and nucleotide stretches were found in strain DKP exclusively or occurred rarely in the 62 members of the genus Bacillus and related genera (e.g., the genus Sporosarcina) whose 16S rRNA sequences are available from the Ribosomal Database Project; these nucleotides, nucleotide pairs, and nucleotide stretches include C at position 189, GAUAA at positions 193.3 to 193.7 , GAUGGC at positions 198 to 203, GCCAUCACUU at positions 214 to $224, \mathrm{U}$ at position $264, \mathrm{U}$ and $G$ at positions 458 and 474 , UCUUGCGGCUCAACCG $\mathrm{CAA}$ at positions 610 to 628 ), $\mathrm{G}$ and $\mathrm{C}$ at positions 835 and 851 ), $U$ and $A$ at positions 999 and 1041), $G$ and $C$ at positions 118 and 1155 , and UCUAG at positions 1120 to 1124 (E. coli numbering as described by Winker and Woese [53]). A bootstrap analysis of the data performed by using programs in the TREECON package and the PHYLIP package revealed low levels of relatedness with members of all three groups; the levels of relatedness with group 1, 2, and 5 strains were 54, 22, and $36 \%$, respectively.

\section{DISCUSSION}

Strain $\mathrm{DKP}^{\mathrm{T}}$, which was isolated from a palm wine sample harvested near Dakar, Senegal, is a moderately thermophilic facultative anaerobe. Its type of metabolism, its low $\mathrm{G}+\mathrm{C}$ content (38.8 mol\%), and its typical gram-positive cell wall (Fig. 1B) suggest that strain $\mathrm{DKP}^{\mathrm{T}}$ could belong to the genus Bacillus or the genus Lactobacillus $(15,44)$.

The morphological and physiological characteristics and nutritional requirements of strain $\mathrm{DKP}^{\mathrm{T}}$ were consistent with the description of the genus Lactobacillus $(19,42)$. Like lactobacilli, strain $\mathrm{DKP}^{\mathrm{T}}$ is non-spore forming, saccharolytic, and chemoorganotrophic. It requires Biotrypcase or yeast extract for good growth. It produces lactate, acetate, ethanol, and formate but not hydrogen during sugar fermentation. Furthermore, $\mathrm{NH}_{3}$ is produced during arginine fermentation, as described previously for heterofermentative lactobacilli (1, 19). The ratio of the molar yields of acetate, ethanol, and formate is $1: 1: 2$; this fermentation ratio is typical of the phosphoroclastic split of pyruvate into formate and acetyl phosphate, where acetyl phosphate produces acetate and ethanol. Unpublished data have shown that the lactate concentration varies considerably according to the culture conditions. In an acidic medium, the yield of lactate increases concomitantly with decreases in the yields of acetate, ethanol, and formate. Under glucose-limiting conditions in a continuous culture, a decrease in lactate production and an increase in the production of acetate, ethanol, and formate occur. These results are consistent with those reported previously for lactic bacteria $(7,11,36,47)$. Furthermore, like members of the genus Lactobacillus, strain DKP ${ }^{\mathrm{T}}$ lacks cytochrome. Nevertheless, it has been demonstrated that under aerobic conditions, lactobacilli reoxidize $\mathrm{NADH}_{2}$, with oxygen serving as the final electron acceptor, since they possess flavin-containing oxidases and peroxidases (19). This process probably results in an increase in acetate production by strain $\mathrm{DKP}^{\mathrm{T}}$ in aerobiosis, as described previously for Lactobacillus plantarum (40).

Despite the phenotypic similarities between strain $\mathrm{DKP}^{\mathrm{T}}$ and the genus Lactobacillus, there are important differences between these taxa. (i) Strain $\mathrm{DKP}^{\mathrm{T}}$ possesses peritrichous flagella, which is unusual in lactobacilli $(19,42)$. (ii) Strain $\mathrm{DKP}^{\mathrm{T}}$ is catalase positive. (iii) Strain $\mathrm{DKP}^{\mathrm{T}}$ exhibits optimal growth in neutrophilic media, whereas lactobacilli grow best in slightly acidic media ( $\mathrm{pH} 5$ or less), with optimal growth occurring at $\mathrm{pH} 5.5$ to 6.2 and growth often reduced at neutral or slightly alkaline $\mathrm{pH}$ values (19). (iv) Strain $\mathrm{DKP}^{\mathrm{T}}$ exhibits an optimum temperature for growth of $50^{\circ} \mathrm{C}$ and the upper temperature limit for growth is $58^{\circ} \mathrm{C}$; most lactobacilli grow best at mesophilic temperatures and have an upper temperature limit for growth of around $40^{\circ} \mathrm{C}$ (the so-called "thermophilic" lactobacilli may have an upper temperature limit of $55^{\circ} \mathrm{C}$, but no strain capable of growth at temperatures above $55^{\circ} \mathrm{C}$ is known [19]). In addition, a comparison of the electrophoretic pattern of the soluble cellular proteins of strain $\mathrm{DKP}^{\mathrm{T}}$ with representative patterns of lactic acid bacteria (Fig. 2; data not shown) also indicated that strain $\mathrm{DKP}^{\mathrm{T}}$ does not belong to any previously described species of lactic bacteria.

The genus Sporolactobacillus, which contains only one species, Sporolactobacillus inulinus (20), is phylogenetically closely related to the genera Bacillus and Lactobacillus. However, Sporolactobacillus inulinus differs from strain $\mathrm{DKP}^{\mathrm{T}}$ by its mesophilic and homolactic characteristics. Moreover, this species produces D-(-)-lactate and does not ferment pentoses. The genus Sporolactobacillus differs from strain DKP ${ }^{\mathrm{T}}$ and the genus Lactobacillus by spore production and from the genus Bacillus by its lack of catalase and cytochrome. The taxonomic position of Sporolactobacillus inulinus has been discussed on the basis of the results of a 16S rRNA sequence analysis (14, $43,44)$, and despite the lack of heme proteins such as catalase and cytochrome, this organism is considered a member of the family Bacillaceae. 
TABLE $1.16 \mathrm{~S}$ rRNA similarity matrix ${ }^{a}$

\begin{tabular}{|c|c|c|c|c|c|c|c|c|c|c|c|c|c|c|c|c|c|c|}
\hline & \multicolumn{18}{|c|}{$\%$ Similarity to: } \\
\hline Taxon & 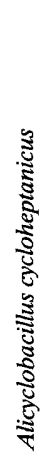 & $\begin{array}{l}\tilde{y} \\
\overline{0} \\
\underline{0} \\
\frac{\tilde{z}}{0}\end{array}$ & 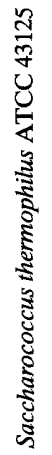 & 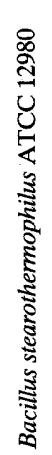 & 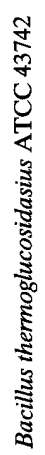 & 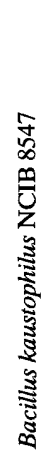 & 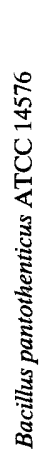 & 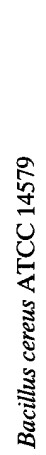 & 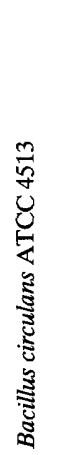 & 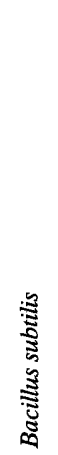 & 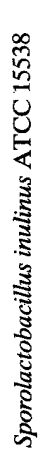 & 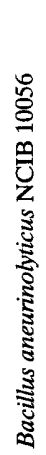 & 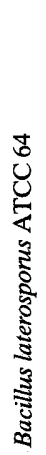 & 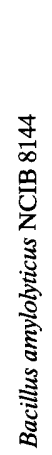 & 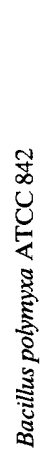 & 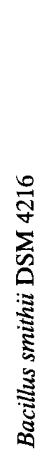 & 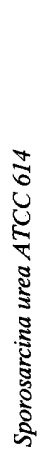 & 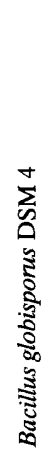 \\
\hline
\end{tabular}

Alicyclobacillus cycloheptanicus 100

Isolate DKP ${ }^{\mathrm{T}} \quad 86.4100$

Saccharococcus thermophilus $\quad 87.3 \quad 94.0100$

ATCC 43125

Bacillus stearothermophilus ATCC 12980

Bacillus thermoglucosidasius ATCC 43742

Bacillus kaustophilus NCIB 8547

Bacillus pantothenticus ATCC 14576

Bacillus cereus ATCC 14579

Bacillus circulans ATCC 4513

Bacillus subtilis

Sporolactobacillus inulinus ATCC 15538

Bacillus aneurinolytius NCIB 10056

Bacillus laterosporis ATCC 64

Bacillus amylolyticus NCIB 8144

Bacillus polymyxa ATCC 842

Bacillus smithii DSM 4216

Sporosarcina urea ATCC 614

Bacillus globisporus DSM 4

$\begin{array}{llll}87.4 & 93.3 & 96.7 & 100\end{array}$

$\begin{array}{lllll}87.4 & 94.8 & 97.5 & 97.3 & 100\end{array}$

$\begin{array}{llllll}87.7 & 93.4 & 96.7 & 99.3 & 97.3 & 100\end{array}$

$\begin{array}{lllllll}86.5 & 94.0 & 95.2 & 93.4 & 94.7 & 93.4 & 100\end{array}$

$\begin{array}{llllllll}86.4 & 93.4 & 94.9 & 93.6 & 94.5 & 93.6 & 95.3 & 100\end{array}$

$\begin{array}{lllllllll}86.2 & 94.4 & 95.8 & 93.8 & 95.0 & 93.8 & 96.9 & 96.2 & 100\end{array}$

$\begin{array}{llllllllll}86.1 & 93.6 & 94.8 & 92.7 & 94.1 & 92.7 & 95.0 & 95.4 & 96.3 & 100\end{array}$

$\begin{array}{lllllllllll}85.0 & 91.6 & 92.7 & 91.1 & 91.9 & 91.1 & 92.7 & 92.4 & 93.3 & 92.8 & 100\end{array}$

$\begin{array}{llllllllllll}87.1 & 91.6 & 92.4 & 91.9 & 92.1 & 91.9 & 91.7 & 91.1 & 92.4 & 91.4 & 89.3 & 100\end{array}$

$\begin{array}{lllllllllllll}85.5 & 90.1 & 90.2 & 90.2 & 89.9 & 90.2 & 90.6 & 90.8 & 90.7 & 89.6 & 88.1 & 91.4 & 100\end{array}$

$\begin{array}{llllllllllllll}86.5 & 89.4 & 90.8 & 89.5 & 90.2 & 89.8 & 90.6 & 90.1 & 91.1 & 90.1 & 88.5 & 90.8 & 90.6 & 100\end{array}$

$\begin{array}{llllllllllllllll}86.3 & 88.8 & 90.3 & 88.8 & 89.3 & 89.3 & 89.7 & 88.8 & 90.3 & 89.0 & 89.1 & 90.2 & 89.8 & 94.4 & 100\end{array}$

$\begin{array}{llllllllllllllll}87.0 & 93.9 & 95.9 & 94.4 & 95.4 & 94.2 & 95.4 & 95.3 & 96.6 & 95.1 & 92.6 & 92.4 & 90.9 & 91.6 & 90.3 & 100\end{array}$

$\begin{array}{lllllllllllllllll}86.0 & 93.4 & 94.7 & 92.7 & 94.1 & 92.7 & 94.0 & 93.6 & 95.4 & 93.4 & 91.5 & 91.5 & 89.7 & 89.4 & 89.6 & 94.9 & 100\end{array}$

$\begin{array}{llllllllllllllllll}86.7 & 92.9 & 94.3 & 92.3 & 93.4 & 92.5 & 93.5 & 93.3 & 95.1 & 93.3 & 91.6 & 91.8 & 90.1 & 89.5 & 90.4 & 95.2 & 97.6 & 100\end{array}$

${ }^{a}$ Values were determined by using Olsen's modification of the method of Jukes and Cantor (see Materials and Methods). Most of the sequences used in this analysis were obtained from the Ribosomal Data Project, version 3.0 (22). The Sporosarcina urea and Saccharococcus thermophilus sequences were obtained from the EMBL. A total of 1,128 unambiguous nucleotides were used in the analysis.

An analysis of the $16 \mathrm{~S}$ rRNA gene of strain $\mathrm{DKP}^{\mathrm{T}}$ revealed that this organism is closely related phylogenetically to members of the genus Bacillus (Fig. 3) as defined by Ash et al. (3); the position of this isolate is equidistantly from the position of members of groups 1,2 , and 5 . However, a detailed analysis of the signature nucleotides found in members of these three groups did not reveal the precise position of isolate $\mathrm{DKP}^{\mathrm{T}}$ in the cluster containing members of groups 1,2 , and 5, indicating that strain $\mathrm{DKP}^{\mathrm{T}}$ is not closely affiliated with any of these three groups. Phenotypically, members of the genus Bacillus and strain $\mathrm{DKP}^{\mathrm{T}}$ are similar since Bacillus species may be facultative anaerobes and usually produce catalase. Bacillus species use oxygen as the final electron acceptor; oxygen can be replaced by alternative electron acceptors in some species (8). However, strain $\mathrm{DKP}^{\mathrm{T}}$ differs from the previously described Bacillus species since it is non-spore forming and does not contain heme proteins such as cytochromes. The possibility that strain $\mathrm{DKP}^{\mathrm{T}}$ produces specific spores which do not exhibit all of the characteristics of Clostridium spores, as described in Thermoanaerobacter finnii (39), was ruled out since strain $\mathrm{DKP}^{\mathrm{T}}$ did not exhibit any heat resistance at $80^{\circ} \mathrm{C}$.
According to Stackebrandt and Woese (44), the genera Bacillus, Lactobacillus, and Streptococcus and a few other genera seem to form a unit, microaerophilic to aerobic in phenotype, which is relatively coherent phylogenetically and is a subbranch of the clostridia. Since the primitive atmosphere of the earth was anaerobic, it has been suggested that among the genera Clostridium, Bacillus, and Lactobacillus, the genus Clostridium is the most ancient. This hypothesis is consistent with the fact that almost all species belonging to this genus are strictly anaerobic and is supported by the results of 16S rRNA studies (44). Accordingly, it has been hypothesized that the genus Bacillus is the most recent genus, because almost all Bacillus species are facultatively anaerobic. The genus Lactobacillus probably appeared between the genera Clostridium and Bacillus. Lactobacilli and, more generally, lactic bacteria possess metabolism which is intermediate between anaerobiosis and aerobiosis. We postulate that strain $\mathrm{DKP}^{\mathrm{T}}$, because of its phylogenetic and phenotypic characteristics, could be a primitive member of the genus Bacillus.

We propose that strain $\mathrm{DKP}^{\mathrm{T}}$ should be placed in the genus Bacillus as a new species, Bacillus thermoamylovorans. 
Description of Bacillus thermoamylovorans sp. nov. Bacillus thermoamylovorans (ther.mo.a.my.lo.vo'rans. Gr. adj. thermos, hot; Gr. n. amylum, starch; L. v. vorare, to devour; M. L. adj. thermoamylovorans, utilizing starch at high temperatures). Gram-positive, straight, rod-shaped eubacteria; cells are 0.45 to $0.5 \mu \mathrm{m}$ wide and 3 to $4 \mu \mathrm{m}$ long, and occur singly or in short chains. Slightly motile by means of peritrichous flagella.

Spores are not detected under a range of conditions; cells are killed by heating at $80^{\circ} \mathrm{C}$ for $5 \mathrm{~min}$.

Facultative anaerobe. Catalase positive. No cytochrome is produced. $\mathrm{NO}_{3}{ }^{-}$and $\mathrm{SO}_{4}{ }^{2-}$ are not reduced. Indole and $\mathrm{H}_{2} \mathrm{~S}$ are not produced.

Heterolactic fermentation of hexoses occurs; the end products are lactate, acetate, ethanol, and formate but not $\mathrm{H}_{2}$.

Chemoorganotrophic. Biotrypcase or yeast extract is required for luxuriant growth. Vitamins and nucleic acid derivatives stimulate growth but are not essential.

Moderately thermophilic. The optimum temperature for growth is about $50^{\circ} \mathrm{C}$; the upper temperature limit for growth is $58^{\circ} \mathrm{C}$.

Neutrophilic. The optimal $\mathrm{pH}$ for growth ranges from 6.5 to 7.5; the $\mathrm{pH}$ range for growth is 5.4 to 8.5 .

The $\mathrm{G}+\mathrm{C}$ content of the DNA is $38.8 \pm 0.2 \mathrm{~mol} \%$.

The results of a 16S rRNA sequence analysis indicate the position of this organism is equidistant from the positions of members of groups 1,2, and 5 of the genus Bacillus.

Isolated from palm wine, an African alcoholic beverage, in Rufisque (near Dakar), Senegal.

The type strain is DKP (= Collection of Institut Pasteur CNCM I-1378).

\section{ACKNOWLEDGMENTS}

We are indebted to K. D. Jahnke, Deutsche Sammlung von Mikroorganismen und Zellkulturen, for the $\mathrm{G}+\mathrm{C}$ content determination We thank P. Roger, A. Haemmerle, J.-L. Cayol, and M. Ramakrishna for revising the manuscript.

B. P. is indebted to the Biotechnology (BRIDGE) T-Project on Lactic Acid Bacteria of the Commission of European Communities (contract BIOT-CT91-0263). We thank the Australian Research Council for financial assistance (to B.K.C.P.).

\section{REFERENCES}

1. Abdelal, A. G. 1979. Arginine catabolism by microorganisms. Annu. Rev. Microbiol. 69:67-70.

2. Ajayi, O. A., E. O. Fakiya, and G. O. Oladopo. 1989. Industrial processing of palm juice and riboflavin loss. Food Chem. 34:89-94.

3. Ash, C., J. A. E. Farrow, S. Walksbanks, and M. D. Collins. 1991. Phylogenetic heterogeneity of the genus Bacillus revealed by comparative analysis of small-subunit-ribosomal RNA sequences. Lett. Appl. Microbiol. 13:202-206.

4. Balch, W. E., G. E. Fox, L. J. Magrum, and R. S. Wolfe. 1979. Methanogens: reevaluation of a unique biological group. Microbiol. Rev. 43:260-296.

5. Barre, P. 1978. Identification of thermobacteria and homofermentative, thermophilic, pentose-utilizing lactobacilli from high temperature fermenting grape musts. J. Appl. Bacteriol. 44:125-129.

6. Bassir, 0. 1968. Some Nigerian wines. West Afr. J. Biol. Appl. Chem. 10:42-45.

7. Carlson, J., and C. J. Griffith. 1974. Fermentation products and bacteria yields in glucose-limited and nitrogen-limited cultures of streptococci. Arch Oral Biol. 19:1105-1109.

8. Claus, D., and R. C. W. Berkeley. 1986. The genus Bacillus, p. 1105-1127. In P. H. A. Sneath, N. S. Mair, M. E. Sharpe, and J. G. Holt (ed.), Bergey's manual of systematic bacteriology, vol. 2. The Williams \& Wilkins Co., Baltimore.

9. Cord-Ruwisch, R. 1985. A quick method for the determination of dissolved and precipitated sulfides in cultures of sulfate-reducing bacteria. J. Microbiol. Methods 4:33-36.

10. De Soete, G. 1983. A least square algorithm for fitting additive trees to proximity data. Psychometrika 48:621-626.

11. De Vries, W., W. M. C. Kapteijn, E. G. van der Beek, and A. H. Stouthammer. 1970. Molar growth yields and fermentation balances of Lactobacillus casei 13 in batch cultures and in continuous cultures. J. Gen. Microbiol. 63:333-345.

12. Eze, M. O., and A. U. Ogan. 1988. Sugars of the unfermented sap and the wine from the oil palm, Elaeis guinensis, tree. Plant Foods Hum. Nutr. 38:121-126.

13. Felsentein, J. 1993. PHILIP (phylogenetic inference package), version $3.51 \mathrm{c}$ Departement of Genetics, University of Washington, Seattle.

14. Fox, G. E., K. J. Pechmann, and C. R. Woese. 1977. Comparative cataloging of the $16 \mathrm{~S}$ ribosomal ribonucleic acid: molecular approach to procaryotic systematics. Int. J. Syst. Bacteriol. 27:44-57.

15. Fox, G. E., E. Stackebrandt, R. B. Hespell, J. Gibson, J. Malinoff, T. A. Dyer, R. S. Wolfe, W. E. Balch, R. S. Tanner, L. J. Magrum, L. B. Zablen, R Blakemore, R. Gupta, L. Bonen, B. J. Lewis, D. A. Stahl, K. R. Luehrsen, K. N. Chen, and C. R. Woese. 1980 . The phylogeny of procaryotes. Science 209:457-463.

16. Heller, R. 1985. Sèves, p. 764-767. In J. Bersani, J. Gall, H. Schweizer, and M. Lardy (ed.), Encyclopædia universalis, vol. 16. Encyclopædia universalis publisher, Paris.

17. Hungate, R. E. 1969. A roll-tube method for the cultivation of strict anaerobes. Methods Microbiol. 3B:117-132.

18. Jukes, T. H., and C. R. Cantor. 1969. Evolution of protein molecules, p. 21-132. In H. N. Munro (ed.), Mammalian protein metabolism. Academic Press, New York.

19. Kandler, O., and N. Weiss. 1986. The genus Sporolactobacillus, p. 1139-1141. In P. H. A. Sneath, N. S. Mair, M. E. Sharpe, and J. G. Holt (ed.), Bergey's manual of systematic bacteriology, vol. 2. The Williams \& Wilkins Co., Baltimore.

20. Kandler, O., and N. Weiss. 1986. The genus Lactobacillus, p. 1209-1219. In P. H. A. Sneath, N. S. Mair, M. E. Sharpe, and J. G. Holt (ed.), Bergey's manual of systematic bacteriology, vol. 2. The Williams \& Wilkins Co., Baltimore.

21. Kunkee, R. E., and M. A. Amerine. 1970. Yeast in wine-making, p. 10. In A. H. Rose (ed.), The yeast, vol. 3. Academic Press, London.

22. Larsen, N. A., G. J. Olsen, B. L. Maidak, M. J. McCaughey, R. Overbeek, T. J. Marsh, and C. R. Woese. 1993. The Ribosomal Database Project. Nucleic Acids Res. 21:3021-3023.

23. Lawson Anani Soh, A., H. Ralambotiana, B. Ollivier, G. Prensier, E. Tine, and J. L. Garcia. 1991. Clostridium thermopalmarium sp. nov., a moderately thermophilic butyrate-producing bacterium isolated from palm wine in Senegal. Syst. Appl. Microbiol. 14:135-139.

24. Love, C. A., B. K. J. Patel, P. D. Nichols, and E. Stackebrandt. 1993 Desulfotomaculum australicum sp. nov., a thermophilic sulfate-reducing bacterium isolated from the Great Artesian Basin of Australia. Syst. Appl. Microbiol. 16:244-250.

25. Macy, J. M., J. E. Snellen, and R. E. Hungate. 1972. Use of syringe methods for anaerobiosis. Am. J. Clin. Nutr. 25:1318-1323.

26. Meshbah, M., U. Premachandran, and W. Whitman. 1989. Precise measurement of the $\mathrm{G}+\mathrm{C}$ content of deoxyribonucleic acid by high-performance liquid chromatography. Int. J. Syst. Bacteriol. 39:159-167.

27. Miège, J. 1985. Palmales, p. 454-457. In J. Bersani, J. Gall, H. Schweizer, and M. Lardy (ed.), Encyclopædia universalis, vol. 13. Encyclopædia universalis publisher, Paris.

28. Miller, T. L., and M. J. Wolin. 1974. A serum bottle modification of the Hungate technique for cultivating obligate anaerobes. Appl. Microbiol. 27:985-987.

29. Okafor, N. 1975. Preliminary microbiological studies on the preservation of palm wine. J. Appl. Bacteriol. 38:1-7.

30. Okafor, N. 1975. Microbiology of Nigerian palm wine with particular reference to bacteria. J. Appl. Bacteriol. 38:81-88.

31. Olsen, G. J. 1988. Phylogenetic analysis using ribosomal RNA. Methods Enzymol. 164:793-812.

32. Pot, B., W. Ludwig, K. Kersters, and K. H. Schleifer. 1993. The taxonomy of lactic acid bacteria, p. 13. In L. De Vuys and E. J. Vandamme (ed.), Bacteriocins of lactic acid bacteria: microbiology, genetics and applications. Blackie Academic \& Professional, London.

33. Pot, B., P. Vandamme, and K. Kersters. 1993. Analysis of electrophoretic whole organism protein fingerprints, p. 493. In M. Goodfellow and A. G. O'Donnell (ed.), Chemical methods in prokaryotic systematics. J. Wiley \& Sons Ltd., Chichester, United Kingdom.

34. Rainey, F. A., N. L. Ward, H. W. Morgan, R. Toalster, and E. Stackebrandt. 1993. Phylogenetic analysis of anaerobic thermophilic bacteria: aid for their reclassification. J. Bacteriol. 175:4772-4779.

35. Redburn, A. C., and B. K. C. Patel. 1993. Phylogenetic analysis of Desulfotomaculum thermobenzoicum using polymerase chain reaction-amplified $16 \mathrm{~S}$ rRNA-specific DNA. FEMS Microbiol. Lett. 113:81-86.

36. Rhee, S. K., and M. Y. Pack. 1980. Effect of environmental pH on fermentation balance of Lactobacillus bulgaricus. J. Bacteriol. 144:217-221.

37. Rogosa, M., J. G. Franklin, and K. D. Perry. 1961. Correlation of the vitamin requirements with cultural and biochemical characters of Lactobacillus spp. J. Gen. Microbiol. 25:473-482.

38. Rokosu, A. A., and J. J. Nwisienyi. 1980. Variation in the components of palm wine during fermentation. Enzyme Microb. Technol. 12:63-65.

39. Schmid, U., H. Giesel, S. M. Schoberth, and H. Sahm. 1986. Thermoanaerobacter finnii spec. nov., a new ethanologenic sporogenous bacterium. Syst. Appl. Microbiol. 8:80-85.

40. Sedewitz, B., K. H. Schleifer, and F. Götz. 1984. Physiological role of 
pyruvate oxidase in the aerobic metabolism of Lactobacillus plantarum. J. Bacteriol. 160:462-465.

41. Shamala, T. R., and K. R. Sreekantiah. 1988. Microbiological and biochemical studies on traditional Indian palm wine fermentation. Food Microbiol. 5:157-162.

42. Sharpe, M. E. 1992. The genus Lactobacillus, p. 1653-1679. In M. P. Starr, H. Stolp, H. G. Trüper, A. Balows, and H. G. Schlegel (ed.), The procaryotes, vol. 2. Springer Verlag, Berlin.

43. Stackebrandt, E., V. J. Fowler, and C. R. Woese. 1983. A phylogenetic analysis of lactobacilli, Pediococcus pentosaceus and Leuconostoc mesenteroides. Syst. Appl. Microbiol. 4:326-337.

44. Stackebrandt, E., and C. R. Woese. 1981. The evolution of procaryotes. Symp. Soc. Gen. Microbiol. 32:1-31.

45. Tchiendji, C. 1985. Ph.D. thesis. Ecole Nationale Supérieure d'Agronomie et des Industries Alimentaires, Université de Nancy, France.

46. Theivendirarajah, K., and R. K. Chrystopher. 1987. Microflora and microbial activity in palmyrah (Borassus flabellifer) palm wine in Sri Lanka. MIRCEN J. 3:23-31.
47. Thomas, T. D., D. C. Ellwood, and V. M. C. Longyear. 1979. Change from homo- to heterolactic fermentation by Streptococcus lactis resulting from glucose limitation in anaerobic chemostat cultures. J. Bacteriol. 138:109-117.

48. Tulley, P. 1965. How to tap an oil palm. Nigerian Field 30:28-37.

49. Ukhun, M. E., and E. N. Dibie. 1991. The ascorbic acid contents of selected marketed foods and influence of water activity $\left(\mathrm{a}_{\mathrm{w}}\right)$ during storage. Food Chem. 41:277-283.

50. Van de Peer, Y., and R. De Wachter. 1992. TREECON: a software package for the construction and drawing of evolutionary trees. Comput. Appl. Biosci. 9:177-182.

51. Van Pee, W., and J. G. Swings. 1971. Chemical and microbiological studies on congolese palm wines. East Afr. Agric. For. J. 36:311-314.

52. Vauterin, L., and P. Vauterin. 1992. Computer-aided objective comparison of electrophoresis patterns for grouping and identification of microorganisms. Eur. J. Microbiol. 1:37-41.

53. Winker, S., and C. R. Woese. 1991. A definition of the domains Archaea, Bacteria, and Eucarya in terms of small subunit ribosomal RNA characteristics. Syst. Appl. Microbiol. 14:305-310. 